\title{
The folklore-centric gaze: a relational approach to landscape, folklore and tourism.
}

IRONSIDE, R. and MASSIE, S.

2020

This is an Accepted Manuscript of an article published by Taylor \& Francis in Time and Mind on 26.08.2020, available online: http://www.tandfonline.com/10.1080/1751696X.2020.1809862. 


\section{The Folklore-Centric Gaze: A relational approach to landscape, folklore and tourism}

Rachael Ironside \& Stewart Massie

Rachael Ironside, School of Creative and Cultural Business, Robert Gordon University, Aberdeen, Scotland, UK

Stewart Massie, School of Computing Science and Digital Media, Robert Gordon University, Aberdeen, Scotland, UK

Correspondence Author: Rachael Ironside

Corresponding Address: 46 Johnston Street, Laurencekirk, AB301AN. Email:

\section{r.j.ironside@rgu.ac.uk}

\section{Biographical Note:}

Dr Rachael Ironside is a Senior Lecturer at Robert Gordon University. Her research interests focus on the role of supernatural folklore, and how it impacts our experience and understanding of place and cultural heritage. Rachael is currently involved in national and international storytelling projects that involve the collection, interpretation and digitisation of local cultural heritage. She is part of the Digital Cities and Society research centre at Robert Gordon University.

Orchid ID: http://orcid.org/0000-0003-2513-0998

Social Media Handle: @DrIronside 
Dr Stewart Massie is a Senior Research Fellow in the School of Computing at Robert Gordon University. His research applies AI technologies, including Case-Based Reasoning and Recommender Systems, to the development of intelligent search solutions. Recent funded projects include tourism applications to improve visitor interaction with objects.

Orchid ID: $\underline{\text { http://orcid.org/0000-0002-5278-4009 }}$

Social Media Handle: @stmassie 


\title{
The Folklore-Centric Gaze: A relational approach to landscape, folklore and tourism
}

\begin{abstract}
Supernatural folktales have a long oral tradition in Scotland, they are embedded in local communities and the landscapes of the region. Recently, these folktales have been utilised by destinations as a form of place-making, and a driver for increasing tourist numbers and engagement. Drawing on a critical discussion of the literature, and case study examples from the Isle of Skye and Orkney Isles, this paper examines the challenges and opportunities offered by folklore tourism. It argues that while folklore tourism presents opportunities for destinations to increase tourism-based revenue, and for the preservation and dissemination of intangible heritage, it also poses challenges to the authenticity and identity of local communities, and the integrity of the natural environment. The experience cultivated by supernatural folktales may, however, also present an opportunity to connect visitors with landscape and community through encouraging participation in liminal and enchanted spaces. By critically exploring the tourist gaze in relation to folklore, this paper invites further research into the value of developing a folklore-centric gaze through the perspectives of animism, and a heritage-centric approach. It is proposed that a folklore-centric gaze may engender a relational approach to landscape, folklore and tourism, and aid in the development of sustainable forms of folklore tourism for the future.
\end{abstract}

Keywords: folklore, tourism, animism, heritage, supernatural, landscape 


\section{Introduction}

"The Stoor Worm's days were finally over. It rose its head up out of the sea in its dying agony and it came back down to earth with a crash, which knocked out a lot of teeth. These teeth fell into the sea and there they remain as the Orkney Islands. The head rose again and crash! More teeth were knocked out and these became Shetland. A third time the head rose and fell with a crash and more teeth were knocked out to make the Faroe Islands. Then the Stoor Worm curled up into a great big lump and died, and there it still remains; only now we call it Iceland. "

- extract from Assipattle and the Stoor Worm by Tom Muir in The Anthology of Scottish Folk Tales

In Scotland, there is a rich storytelling heritage connecting folklore and landscape. Like the Stoor Worm, these tales speak of mystical and otherworldly influences upon the environment; creatures that moulded hills and lochs, witches that influenced land and seas, and supernatural beings that inhabit the glens and coast. These stories have a long oral tradition in Scotland passed down through generations. However, like many destinations in our contemporary world they perform a dual role, operating as a resource for both tourism production and experience.

Research on folklore has examined the opportunities and challenges that this dual role poses for local communities (Henriques \& Custódio, 2008; Light, 2007). However, much of this research has focused on the cultural commodification and issues of authenticity that the reproduction and performance of folklore through customs such as song, dance and music can present (Bruner, 2001; Storey, 2009). This paper will focus on a specific subset of 
folklore, the supernatural folktale, and its relationship with both landscape and tourism. A supernatural folktale, such as the story of the Stoor Worm above, is an oral tale of supernatural creatures, events or activities, that has been passed down through generations within a community. In recent years, exploring the landscapes associated with supernatural folktales has become a popular past time for tourists, with destinations and businesses across the tourism, hospitality and events industries embracing this turn to the extraordinary (Ironside, 2018; Mathe-Soulek, Aguirre \& Dalinger, 2016; Meehan, 2008). The popularity of these tales has, however, led to consequences that threaten the relationship between folklore, landscape and the tourist. Indeed, over-commodification of folktales threatens both the authenticity and identity of communities, while over-tourism has led to increasing environmental and ecological concerns in some locations.

This paper draws on case study examples of the relationship between supernatural folktales, landscape and tourism on two Scottish islands; The Isle of Skye and Orkney Isles. Both islands have a rich storytelling heritage, with supernatural folktales utilised as a method to attract visitors and encourage engagement with the landscape. These case studies will be used to develop a broader discussion, drawing critically on literature about this relationship to consider the challenges and opportunities raised by this relationship, the tourist experience with folktales, and the value of developing a relational approach to folklore tourism that draws upon heritage, place and notions of animism to construct a 'folklore-centric' gaze. This is a conceptual paper, that invites further research into these ideas with the intention of proposing an approach to folklore tourism that is more sustainable for the future. 
Case Study: Isle of Skye

The Isle of Skye is situated on the West Coast of Scotland. Accessed by the Skye Bridge, the island with a population of just over 10,000 residents is frequently considered to be one of the most desirable places to live in the UK (Shaw, 2016). Famous for its remote and rugged landscapes, the island attracts visitors inspired by these dramatic scenescapes, as well as the history, heritage and food culture of the island.

The landscape and heritage of Skye, are also embedded in the folklore traditions of the island. The Old Man of Storr ('Bodach an Stòrr' in Gaelic), a rocky outcrop along the Trotternish Peninsula, is said to have been formed by a giant who was buried with his thumb sticking out from the ground. Another enduring legend is that of the Fairy Bridge ('Beul-Ath nan Tri Allt'), rumoured to be the location where the Fairy Flag was exchanged between a fairy and her lover on her departure. The story tells that the flag, now located in Dunvegan Castle, has the power to protect and save the MacLeod Clan three times.

Other locations on Skye embody folkloric associations due to their unique geological features. The Fairy Glen is one such example. Located in Uig along the North East peninsula, the glen features a miniature landscape of small hills, lochs and trees which give it an otherworldly quality and has thus been named, 'The Fairy Glen'. One hill still has a basalt rock formation visible at the top and has been nicknamed Castle Ewan, also known as the 'Fairy Castle'.

In 2017, it was estimated that over 150,000 tourists visited the Isle of Skye (Carrell, 2017). Many of these tourists travelled to island locations associated with the many picturesque landscapes promoted through recent films and social media. The Fairy Glen is a small, 
hidden landscape, and known until relatively recently only by residents. However, the rise of tourism on the island and the popularisation of the Fairy Glen have led to unexpected consequences.

The Fairy Glen now features on the tour route of a number of coaches travelling to the island. As a result, the small one-way roads leading in and out of the glen struggle to accommodate the new influx of traffic. The landscape of the Fairy Glen has also changed dramatically. The natural features of the landscape have been replaced by manmade cairns, stone circles and spirals (see figure 1). These new features are the result of tour guides encouraging visitors to take part in practices to appease the fairies. This includes moving stones to build cairns, marking them with coloured pens, and walking backwards around circles dropping stones in a spiral pattern. These practices, and the folklore narratives that have been constructed to accommodate them, do not have an indigenous tradition in the glen. They have been invented in response to the environment and presumably in an effort to meet the increasing need to satisfy tourist curiosity and enhance their experience.
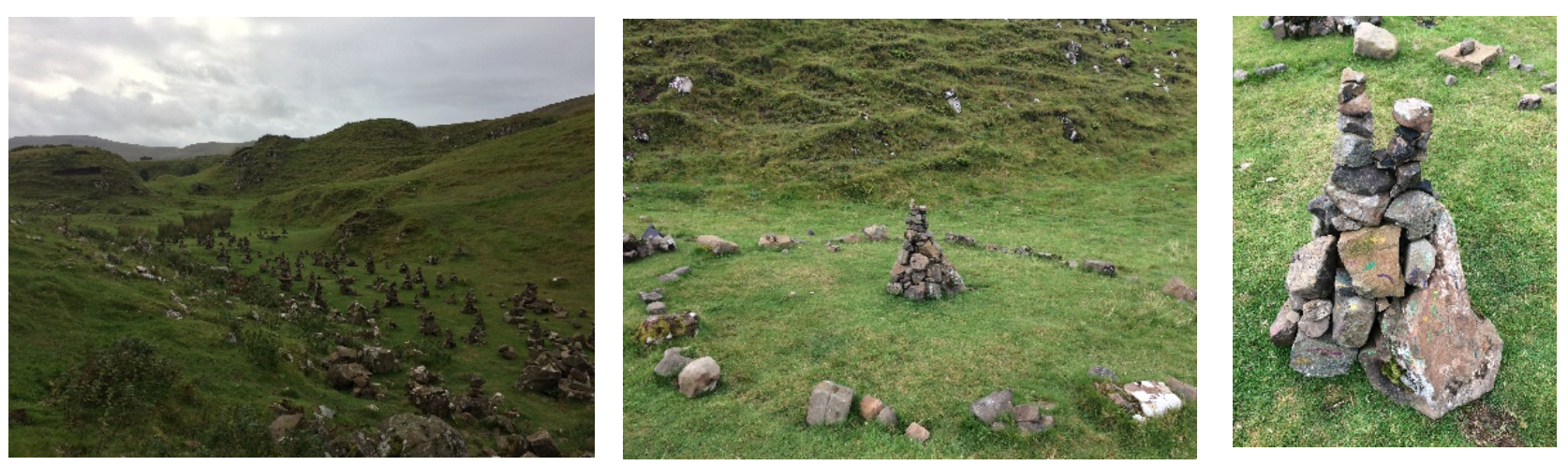

Figure 1. Stone circles and cairns created by tourists in the Fairy Glen

The negative impacts of these changes are experienced ecologically and by local communities as the landscape degrades and changes as a result of tourist behaviour (The Scotsman, 2019). Local communities are also impacted by the increased traffic, and for some 
living in the area there is discomfort at becoming the subject of an increased tourist gaze. This has led to community groups rallying to combat the rise in tourism and preserve the natural features of the landscape (The Times, 2018). At the end of each season communities come together to remove the manmade features in an attempt to return the landscape back to its natural state.

\section{Case Study: Orkney Isles}

The Orkney Islands sit as an archipelago on the North-Eastern coast of Scotland. The collection of more than 70 islands are renowned for their abundance of Neolithic sites, including the 'Heart of Neolithic Orkney' - a group of 5000-year old sites on the mainland including Skara Brae and Maeshowe. Orkney also has a rich storytelling and folklore heritage, hosting a world-famous storytelling festival in October each year (Orkney Storytelling Festival, 2019).

Over the last ten years, Orkney has seen a significant increase in tourism with figures suggesting that volume tourism has risen by 160\% between 2011-2016 (Orkney Volume Tourism Management Survey, 2017). In 2017, Orkney welcomed 170,000 visitors with a significant number of tourists arriving via cruise ship. This has caused strain on the local community, resources and natural environment (Brockehurst, 2017; The Herald, 2017). In particular, those sites associated with Orkney's Neolithic heritage have seen a considerable growth in visitor numbers. This has led to a call from the Orkney Islands Council and Highlands and Islands Enterprise for measures to be put in place to alleviate the problems caused by volume tourism. 
In response to a call for innovative ways to disperse tourism on the islands, the Orkney Folklore Trail was developed in 2019 as a collaboration between Robert Gordon University and Orkneyology (an organisation run by local folklorist Tom Muir, and his wife Rhonda Muir). The trail is a digital Android app which features ten locations on Orkney where visitors can 'unlock' folklore stories narrated by Tom Muir. Using GPS technology, the app restricts the content available to the user until they visit the locations on the trail with the purpose of encouraging people to explore less frequently visited areas of the island. At each location the user is presented with a number of audio and written folklore stories, images and further details about the location (see figure 2). Stories are delivered in such a way as to encourage visitors to look away from their phones and to engage with the landscape around them.

"As you stand on the shore here at Warbeth, looking out over the Atlantic Ocean, you will see the island of Hoy on your left. The headland that slopes down to the sea is called the Kame of Hoy. On your right you can see the pointed headland called Breckness. There are the ruins of an old 17th century house there, which formerly belonged to Bishop Graham. The land then rises up to form the Black Craig. Here I am going to tell you a story about a mermaid, a shipwreck and why you don't see fairies around here anymore..." (extract from the Orkney Folklore Trail, 2019)

The app also directs visitors to small businesses in the area including cafes, shops and lesser visited attractions. In doing so, the purpose of the app is to explore the potential for folklore 
to be used as a tool to engage visitors and locals with the landscape, heritage and culture of Orkney by providing an alternative attraction to popular visitor sites.
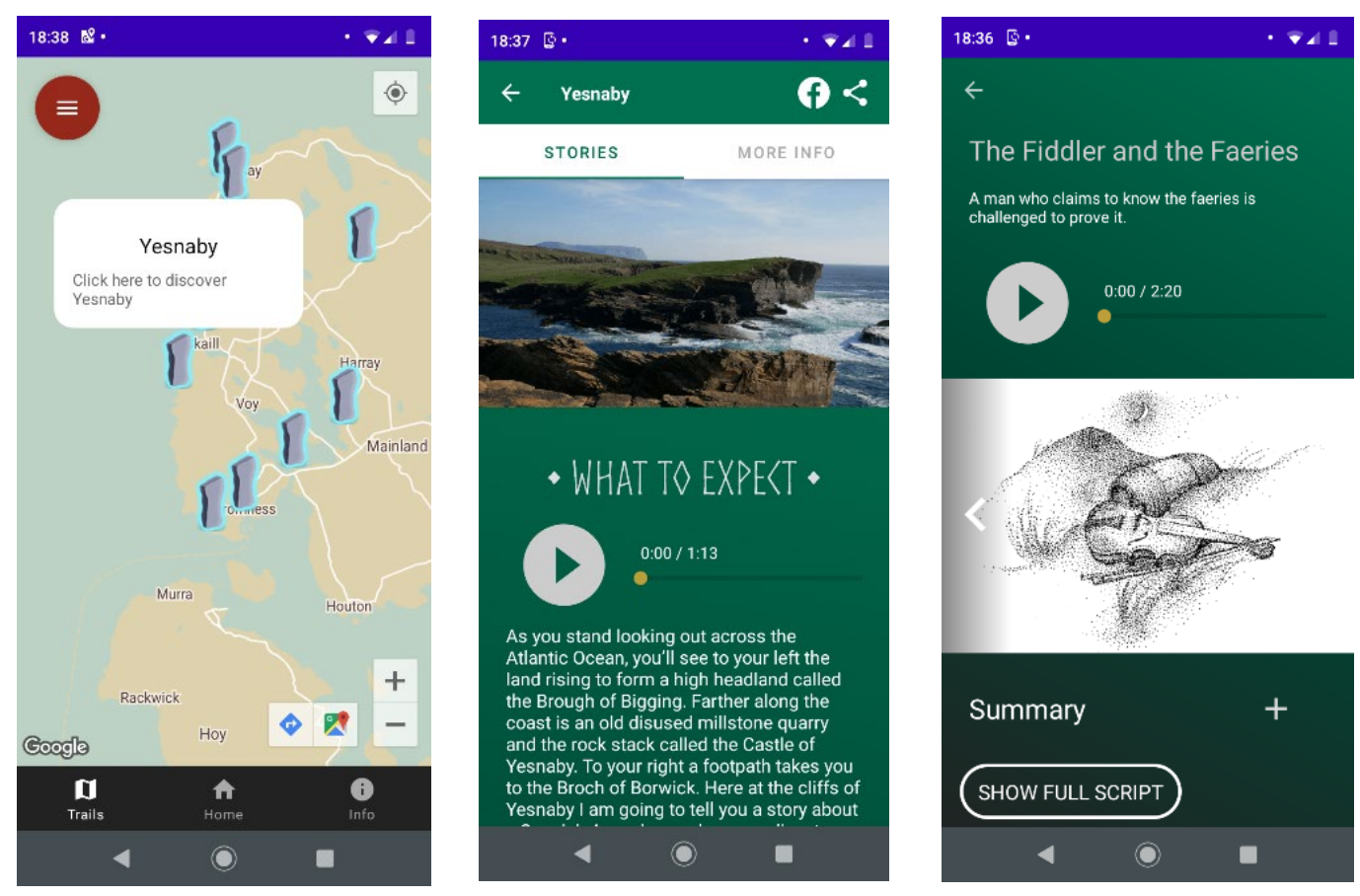

Figure.2. Screenshots from the Orkney Folklore Trail

\section{Folklore, Landscape and the Tourist}

The use of folklore as a resource for tourism is widely recognised amongst scholars (Earl, 2008; Hemme, 2005; Ironside, 2018; Light, 2007). In the Scottish context, supernatural folktales have long been ascribed to the landscape, romanticised through stories of a mythical Celtic past and the ghostly apparitions created by Sir Walter Scott. In the early $19^{\text {th }}$ Century, guidebooks recommended locations to visit based on the works of Sir Walter Scott and the extraordinary character of the places he imagined. More recently, the Ross-shire Journal reported that Nessie sightings were the highest they had been since 1983 (Ross-shire Journal, 2020), and in 2018 a study suggested that the visitor economy around Nessie was worth over 
$£ 41$ bn (The Press \& Journal, 2018), illustrating the enduring quality of the Loch Ness Monster legend. As Inglis and Holmes (2003) discuss, the landscape and identity of Scotland has long been intertwined with the mystical and otherworldly.

In Scotland, and further afield, the role of folklore, landscape and the tourist is contested. For destinations, folklore stories can be a valuable marketing resource to promote locations with rich storytelling heritage (Mathe-Soulek, Aguirre \& Dalinger, 2016). It can also help to reimagine and reconstruct the image of destinations that have struggled to reach the tourism market in more conventional ways (Light, 2007; Meehan, 2008). Dracula tourism in Romania (Light, 2007), and UFO tourism is Roswell, USA (Meehan, 2008), are examples of destinations that have put themselves on the 'tourism map' due to the legends and folklore associated with them. In these instances, landscape is crucial to the tourism narrative, which is engendered through mystical and otherworldly characteristics. For instance, the imagery and discourse surrounding Bran Castle, Transylvania, plays on the Dracula myth and the remote, uncanny qualities of the castle regardless of the accuracy of the link between the site and the Bram Stoker novel (Light, 2007).

The economic benefits of 'packaging' folklore as a product for tourist consumption is a significant driver for the use of stories in this context. However, others have argued for the wider value of tourism in helping to preserve and disseminate intangible heritage that may be at risk of being lost or forgotten (Koläs, 2004). The public interest in folklore and storytelling, provides an opportunity to engage and educate visitors about the history and heritage of a location (Gentry, 2007; Hanks, 2015; Holloway, 2010; Light, 2007). As recognised by Hanks (2015) in her study of haunted heritage in the UK and USA, the ghost stories delivered during tours of destinations invite listeners to consider these stories within a 
much broader political, religious and historical narrative. They provide a 'backstage' glance, uncovering hidden or less polished versions of how places are presented through the conventional tourism literature (Holloway, 2010). Ghost stories have the potential to engage visitors in a 'mythico-history' (Malkki, 1995) where historical fact is embellished and intertwined with a wider mythical potential. Folklore has also been recognised by wider disciplines as an educational tool and for the interpretation of place, environment and heritage (Hopper et al, 2019; Paphitis, 2013). As such, folklore is considered to be a valuable resource for the promotion of destinations, increasing their economic potential and engaging visitors while they are there. In return, tourism provides the opportunity to preserve oral tradition, and disseminate this to new and emerging audiences.

Despite this positive relationship, there are concerns that the commodification of folklore in this way can lead to negative consequences. As recognised by Koläs (2004) and others (Goldstein, Grider \& Thomas, 2007; Light, 2007), using folklore as a tool for 'place-making' raises questions about who is best placed to establish these narratives, and to represent destinations in their image. A neo-liberal approach to capitalising on folklore, has the potential to shift power away from those communities that folklore is embedded within, and towards those stakeholders with a profit-led agenda. This can lead to a conflict between “identity vs. economy” (Tunbridge, 1994), and significant socio-cultural and environmental impacts. For destinations such as Transylvania, their association with the Dracula legend has been met with resistance by local communities who perceive the association between the vampire-myth and Vlad Țepeș (for some a national hero) as culturally insensitive (Light, 2007). For other destinations, heritage becomes so enmeshed in folklore that 'fact' and 'fiction' become inseparable leading to the fragmentation of historical and personal narratives (Goldstein, Grider and Thomas, 2007). 
The popularity of places associated with folklore, also raises significant environmental concerns. The case study of the Isle of Skye and the Fairy Glen, referred to above, is an example of folklore stories being packaged and reinterpreted to fit a commercial agenda. The landscape of the Fairy Glen inhabits a small area of the island, with a single track road and little in the way of established tourism infrastructure. The high volume of tourism to this destination, has caused significant ecological damage heightened by the pseudo-spiritual practices (including creating stone circles and spirals) that are encouraged by tour providers. Local community groups have established campaigns to prevent the damage to the Glen, with regular 'clear ups' to remove the stones, and an online presence to try to educate tourists. Environmental problems that emerge from an association with folklore are not isolated to the Fairy Glen with similar reports of ecological damage caused by souvenir collecting at sites such as the Fortingall Yew Tree in Perthshire (The Times, 2019). Waskul \& Waskul (2016) also observe that the desecration of a graveyard in Loon Lake Cemetery, USA, was due to a legend of the land being a 'witches graveyard'. In contrast, the Orkney Folklore Trail was designed with the intended purpose of reducing environmental damage to high-volume tourism sites on the island. Orkney is known for its key heritage sites including Skara Brae and the Ring of Brodgar, however, the damage caused to these sites has led to recent calls to find alternative ways to disperse tourism on the island. The propensity of folklore on Orkney, and its link to specific landmarks, presented an opportunity to encourage tourists to explore a broader range of locations minimising ecological damage to popular sites, and "enlivening" every day (and less visited) spaces through these stories (Gentry \& Alderman, 2015). This dual role of folklore in the landscape - both potentially preserving and damaging natural habitats - is also observed in Holmes et al's (2018) research into the role of 'magical animals' in conservation. 
The relationship between folklore, landscape and tourism is therefore complex.

Economically, studies suggest that the packaging of folklore and landscape is a successful strategy for place-making, and tourism-based revenue. It could also be argued that tourism provides a vessel through which oral tradition is maintained and preserved. However, folklore tourism presents significant challenges in maintaining the integrity and authenticity of these traditions, and the communities they represent. Furthermore, the landscape and ecology of place has the potential to be put at risk by the stories that have emerged from it. As such, if a relationship is to be fostered between folklore, landscape and tourism a closer examination of the complex issues surrounding it are required.

\section{Experiencing the landscapes of supernatural folktales through tourism}

To achieve a better understanding of this, and to consider how a positive relationship can be fostered, an examination of the experiences that supernatural folktales can facilitate in places may be useful. As discussed above, experiencing folklore in landscape is a popular activity for tourists, making it a profitable resource for destinations and tour operators. The delivery of folklore also has entertaining qualities, drawing upon artful storytelling and the listener's imagination. As Thompson (2010) explores in his study of ghost tour guides, those that perform the role of storyteller are often aware of the entertaining qualities of these stories, intertwining their delivery of darker stories with a 'nip' and 'bite' of playfulness to keep audiences engaged. However, beyond entertainment folklore is also recognised as providing a more meaningful experience for visitors. 
Experiencing supernatural folktales can provide a departure from the everyday. The characteristics of folk stories, and particularly those of a supernatural nature, provide an otherworldly perspective, filling everyday spaces with fantastic tales and legends (Gentry, 2007). In doing so, as Pritchard and Morgan (2006) emphasise, they create a space "between the mundane and the extraordinary" (pp. 764). As a result, folktales can provide a different experience of landscape, seen not only for its physical characteristics but becoming a mystical heterotopic space with multiple, and fragmented meanings (Carruthers \& Krisjanous, 2014). In this way, landscapes of folklore provide an opportunity to experience enchantment, and to imagine and consider extraordinary possibilities (Holloway, 2010). The desire to experience supernatural folktales is perhaps influenced by the enchanted spaces they create, in what may be perceived as an increasingly disenchanted world.

"Enchantment can be a state in which ghosts, spirits, and spectres exist within a melange of other marvels, including magic, myth, monsters, witchcraft, sorcery, voodoo, vampires, and zombies.... Such marvels are no longer thought to have been exorcised by the rational and secular processes of modernity; far from being extraneous to modernity, they are intrinsic to what are increasingly recognised as thoroughly enchanted modernities." (McEwan, 2008 pp. 30)

By enchanting landscapes, and creating a space in-between the ordinary and extraordinary, supernatural folktales serve to create liminal spaces (Pritchard and Morgan, 2006). Tourists are invited to play with the possibility of a landscape where standing stones come to life to drink from the loch (as on Orkney), or fairies inhabit the Glen (as in the Isle of Skye). While these stories may seem far beyond the limits of usual rationale thought, they nevertheless provoke imagination and contemplation. As illustrated in the example of the Fairy Glen, 
stories may even change tourist behaviour, or encourage immersion in the legend by participating in 'magical' rituals with the 'possibility' that this will bring luck to the traveller. In this instance, the tourist becomes part of the performance of and in these landscapes (Shelley and Urry, 2004) (see figure 3). In a similar way to Light's (2007) observation in Transylvania this performance supports and reproduces the 'place-myth' of the Fairy Glen in different ways.

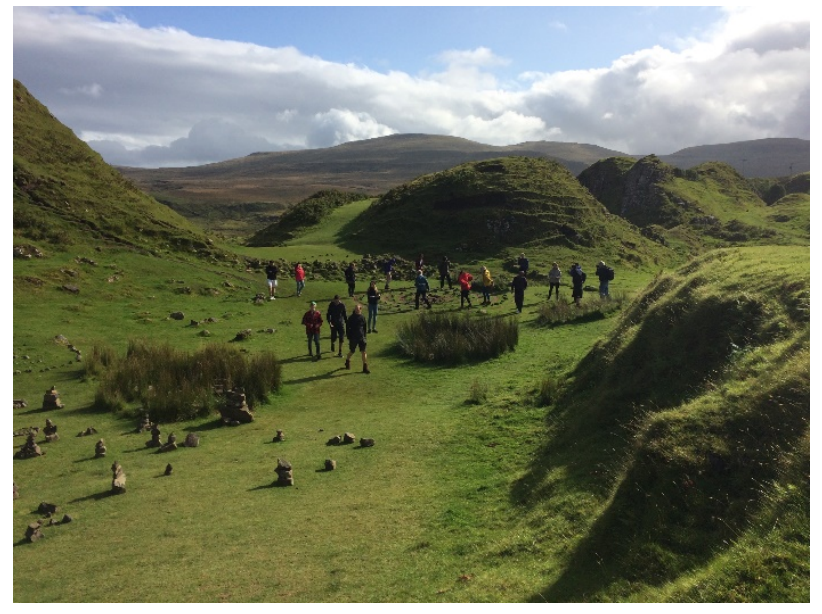

Figure 3. Tourists taking part in a ritual by walking backwards around a circle and dropping stones in the Fairy Glen.

In the context of the Fairy Glen this poses a challenge for the landscape which comes to be seen as a place of carnivalesque 'play' evoked by folktales and the liminal spaces created by them (Turner, 1982). However, liminality is also recognised as providing the possibility for transformative experience. While the state of liminality suspends normality and fixed social structures, at the same time it facilitates a transition from one state of being to another (Stenner, 2017). In this transitional state, individuals may be open to new perspectives on social, cultural and environmental practices (Axsen, TyreeHageman \& Lentz, 2011). As such, the liminal experiences induced by supernatural folktales have the potential to influence and 
shape tourist behaviour. This might be an example of the educational value of folklore, where it is utilised as a resource for communicating cultural and environmental information through connection to the landscape, heritage and local community.

\section{Constructing a 'folklore-centric' gaze}

In 1990, John Urry proposed his theory on the tourist gaze, which considered the ways tourists 'see' the objects, landscapes and practices of their tourist experience. Latterly, Larsen \& Urry (2011) expanded this theory to incorporate not only the visual aspects of tourist gaze, but the wider performative relationship. The tourism experience, they reflect, is multisensuous and embodied. As such, gaze and performance are not separate paradigms but “dance together” (pp. 1111).

The way that tourists 'see' and gaze upon landscapes of folklore has important implications for how these environments are subsequently experienced, and consumed by visitors. As already discussed, the discourses around certain destinations - such as Transylvania and Roswell - construct a particular 'way of seeing' the landscape and culture, even before a physical journey has taken place (Light, 2007; Meehan, 2008). Tourism literature, guides and local attractions can often reinforce this preconception of the landscape, and encourage behaviour, or facilitate experiences, that reinforce this perspective. The Fairy Glen is an example of this. Online sources describe the landscape as 'magical' and a 'home to the fairies', while tour guides encourage the creation of stone cairns and circles. Over time, this has caused the physical landscape of the Fairy Glen to shift to accommodate the tourist gaze. The numerous stone cairns and circles that have appeared, have created a landscape that is perhaps more in line with the tourist expectation of what a 'home to the fairies' would look 
like. Tourists become, in this sense, co-creators and re-inventors of the folklore, landscape and tourist gaze at particular sites and locations.

This approach to the construction of the tourist gaze in landscapes of folklore can be detrimental, and lead to social, cultural and environmental concerns. Folklore becomes a product of tourism consumption (Henriques \& Custódio, 2008) and is seen through the gaze of entertainment rather than connected to the heritage, community and landscape it originates from. This is perhaps unsurprising when considering how supernatural folktales are packaged through wider media, entertainment and commercial outlets (Hill, 2010; Ironside, 2018). In this final section, we consider an approach to tourism in landscapes of folklore that proposes shifting the 'tourist gaze' to a 'folklore-centric gaze' through the lens of heritage and animism. These are very early considerations that rather than propose answers, invite further enquiry and research.

\section{Folklore tourism as heritage and place centric}

Although folklore is considered by scholars to be a form of intangible heritage (KirshanblattGimblett, 2004), its reproduction as a tourism resource can lead to a disconnect between folklore and the community heritage it originates from (Henriques \& Custódio, 2008). As already discussed, this results in the cultural identity and heritage of places being perceived through a different gaze by the tourists that visit, and those communities that the performance of folklore is intended to represent (Larsen \& Urry, 2011; Light, 2007). As illustrated above, supernatural folktales are particularly vulnerable to this as they are often re-packaged as forms of entertainment. 
However, others have argued that folklore that is delivered with local heritage and education at its core has the potential to offer wider benefits, not only to visitors but to communities as well (Baron, 2016; Henriques \& Custódio, 2008). The Orkney Folklore Trail was created as a collaboration with local storytellers. They were passionate about folklore, but also preserving the environment and benefitting local communities. As such, the folklore trail offers a number of stories told by Tom Muir, but also includes additional information about local heritage, the natural environment and small businesses on the island. The trail is not simply about entertaining its users, but educating and inspiring them to consider the wider community and natural environment of the destinations they visit. As a result, the trail has attracted tourists, but also a considerable number of local users who have participated in the tour to expand their own knowledge of the folklore and heritage of the island. Hemme (2005) observes similar success in Reinhard's Forest along the 'German Fairy Tale' route. Tours of the forest are provided by a local guide, Herr Uffelmann, who offers visitors an authentic experience of the forest based on his own personal narrative from many years living near, and exploring the forest. Herr Uffelmann performs the role of Knight Dietrich on his tours and in doing so plays to the imagination and entertainment expected by visitors. However, as Hemme (2005) explains, he also offers a richer experience of the heritage and landscape of the region by delivering a narrative of folklore that is tied to the natural environment, heritage and his own personal interpretation of the space. The natural environment and landscape of the forest is integral to this, and promoted as an 'ecomuseum' (Hemme, 2005). Folklore is, therefore, part of the experience offered to tourists, but is itself embedded in the broader frameworks of heritage, landscape and community.

As recognised in wider heritage and tourism studies (Baron, 2016; Brown \& Cave, 2010; Dragouni, 2017; Waterson \& Smith, 2010), the dissemination and delivery of folklore 
narratives for tourist purposes must be respectful of the identity and heritage of local communities. The Fairy Glen has seen conflict between local communities and tourists, as a result of new folklore being invented by tour guides to enhance the experience, rather than originating from the traditions of the community itself. Alternatively, the Orkney Folklore Trail is community-led, with traditional folklore stories told from the perspective of community stakeholders. A dialogic approach to folklore collection and delivery that involves communities (Baron, 2016), and is heritage and place centric, has the potential to foster a more positive relationship between communities, tourists and the landscape. As identified by Grydehøj (2010), "recognition that tradition and heritage are locally determined and always evolving is a precondition for their effective preservation and exploitation" (pp. 87). Supernatural folktales, when considered as intangible heritage, should be afforded the same community-led approach that is valued in wider heritage engagement.

\section{Folklore tourism and animism}

In earlier sections of this paper, the ability for folklore to enliven everyday spaces was considered (Gentry \& Alderman, 2015). Kirschenblatt-Gimlett (2004) also argues that, "like tangible heritage, intangible heritage is culture, like natural heritage, it is alive. The task then, is to sustain the whole system as a living entity and not just to collect 'intangible artefacts"” (p53). In this final section, we would like to draw upon the notion of viewing intangible heritage, and specifically supernatural folktales, as enlivening and indeed 'living' in landscape. When we consider the stories told in supernatural folktales, many of them contain narratives that breathe life into the landscape. In Orkney, the folklore of the 'moving stones' offers a good example. A number of the standing stones are said to 'come to life' at Hogmanay, and hop down to the nearby loch for a drink. Aside from movement, the stones often embody human characteristics. The Stone of Quoyboon, for instance, is described as a 
"different character to the rest" and a "killer" that chooses to crush any person who tries to sneak a peek at it moving to the loch (Orkney Folklore Trail, 2019). Tales of mounds in the ground as homes to Hogboons (translated from Old Norse as 'mound-dweller', an ancestral gaurdian spirit - with a poor temper - believed to inhabit a burial mound on an island farm), and the Glens as home to the Fairies also offer an enlivened perspective of the landscape.

In their paper, McCann and Hsu (2014) propose a new form of tourism which they call Animistic Ecotourism. They argue that using storytelling to relate the role of animism in different cultures, may provide a way to simultaneously preserve oral tradition, and connect visitors to place, culture and the natural world. Since this proposition, surprisingly little research has focused on the concept of Animistic Ecotourism as an approach to the delivery of intangible heritage and folklore in tourism. However, scholars have noted a marked shift towards reconsidering animism, and the role it plays in connecting people with landscape (Harisa-Buck, 2012; Hunter, 2019; Matter, 2012; Seller, 2010). In its traditional scholarly usage, animism has referred to a belief that the world is populated by 'spirits' (Matter, 2012), however, more recently a 'new animism' has emerged that moves away from the potentially troublesome attribute of 'spirits', and instead refers to the idea of 'persons':

"Animists are people who recognise that the world is full of persons, only some of whom are human, and that life is always lived in relationship with others. Animism is lived out in various ways that are all about learning to act respectfully (carefully and constructively) towards and among other persons. Persons are beings, rather than objects, who are animated and social towards others (even if they are not always sociable). Animism ...is more accurately understood as being concerned with learning 
how to be a good person in respectful relationships with other persons" (Harvey, 2005, pp. xi).

The notion of treating the landscape as if it were 'really' a person, may be an uncomfortable position for some. However, Hunter (2019) discussed an approach that considers landscape and ecology as if it had personhood, rather than necessarily believing this to be true. This, he suggests, could provide positive benefits to the environment. If the Fairy Glen, for instance, was considered through the gaze of animism, rather than consumerism, it might encourage tourists to look upon the landscape differently. It could engender more respectful behaviour just in case disturbance to this space negatively impacts the landscape, in the same way it would a person. Perhaps visitors would be less inclined to disturb the landscape if it was 'seen' as home to certain persons, rather than as an empty space for tourist consumption. The stories of the moving stones to some extent already achieve this by ascribing a form of personhood to the stones, and articulating the consequences of disturbing them.

In many ways, folklore already offers an alternative way of seeing landscape, and a liminal space to experience the possibility of animism. However, the commodification of folklore in these spaces and the negative consequences apparent in examples like the Fairy Glen, suggest that more can be done to shift the tourist gaze away from consuming landscapes of folklore, towards a relational perspective that encourages a "human-natural-supernatural sociality" (Matter 2012, pp. 152). Considering folklore tourism through the lens of animism and a heritage-place centric approach may be a useful avenue for further research. 


\section{Conclusion}

In this paper, the relationship between folklore, landscape and tourism has been considered. It is evident that tensions exist within this relationship as the value and purpose of folklore in tourism can be viewed through multiple, often competing, lenses. Much like the fragmented meanings that supernatural folktales evoke in the landscape, so too does it fragment the different ways that communities, tourists and organisations gaze upon landscapes of folklore. Drawing upon previous studies this paper presents some initial reflections on the role that a heritage-place centric approach and an animistic perspective might play in reducing these tensions. These are preliminary observations that invite consideration on how supernatural folktales may be used to shift the tourist gaze to engender more meaningful encounters with landscape and community. As discussed, supernatural folktales provide an opportunity to foster experiences of enchantment and construct liminal spaces for tourists to consider alternative perspectives. It is evident that supernatural folktales are enjoyed as an entertaining experience, and this approach does not suggest that entertainment should not be part of how folklore is engaged with by visitors. However, previous examples of folklore tourism in practice suggest that an approach that is sensitive to the heritage value, community and landscape, still has the potential to evoke enjoyment for visitors, while also encouraging respect for the wider natural and social environment.

In his introduction to The Anthology of Scottish Folk Tales, Donald Smith, Director of the Scottish International Storytelling Festival states (Smith, 2019), writes that: 
"these stories matter because they bring us closer to the natural world, to our shared centuries of human endeavour, and to sustaining values. Never has the world had so much need of such stories..."

We are at a critical point in time where our responsibility to and relationship with the natural world requires immediate reflection. Supernatural folktales have a long history of weaving the mythical and natural to connect us to the world, and by enchanting everyday spaces with extraordinary possibilities these stories have influenced the way we see, experience and behave in certain spaces. As scholars, it is perhaps time to explore how folktales can connect us to our contemporary world and build a pathway to a more sustainable and enchanted future.

\section{Acknowledgments}

We would like to thank Tom and Rhonda Muir who worked with us on the development of the Orkney Folklore Trail, and inspired us with the wonderful folklore and stories of the island. It has given us much to consider. We would also like to thank Professor Peter Reid for his review of this paper, and for his encouragement and enthusiasm on all aspects of cultural heritage.

\section{References}

Axsen, J. , J.TyreeHageman, and A.Lentz . 2012. "Lifestyle Practices and Pro-Environmental Technology.” Ecological Economics 82: 64-74. doi:10.1016/j.ecolecon.2012.07.013.

Baron, R. 2016. "Public Folklore Dialogism and Critical Heritage Studies.” International Journal of Heritage Studies 22 (8): 588-606. doi:10.1080/13527258.2016.1150320. 
Brocklehurst, S. 2017. “Orkney copes with cruise ship invasion.” Accessed 29 May 2020. https://www.bbc.co.uk/news/uk-scotland-40731839

Brown, K. G. , and J.Cave . 2010. "Island Tourism: Marketing Culture and Heritage Editorial Introduction to the Special Issue." International Journal of Culture, Tourism and Hospitality Research 4 (2): 87-95. doi:10.1108/17506181011045163.

Bruner, E. M. 2001. “The Maasai and the Lion King: Authenticity, Nationalism, and Globalization in African Tourism.” American Ethnologist 28 (4): 881-908. doi:10.1525/ae.2001.28.4.881.

Carrell . 2017. "Skye Islanders call for help with overcrowding after tourism surge.” Accessed 05 April 2020. https://www.theguardian.com/uk-news/2017/aug/09/skyeislanders-call-for-help-with-overcrowding-after-tourism-surge

Carruthers, J. , and J. Krisjanous, J. (2014). “The Ghostscape: Developing a Servicescape for Ghost tourism." In Paper presented at Academy of Marketing (2014) Marketing Dimensions : People, Places and Spaces.

Dragouni, M. , 2017. Sustainable heritage tourism: Towards a community-led approach (Doctoral dissertation, UCL (University College London).

Earl, B. 2008. "Literary Tourism: Constructions of Value, Celebrity and Distinction.” International Journal of Cultural Studies 11 (4): 401-417. doi:10.1177/1367877908096003. 
Gentry, G. 2007. "Walking with the Dead: The Place of Ghost Walk Tourism in Savannah, Georgia.” Southeastern Geographer 47 (2): 222-238. doi:10.1353/sgo.2007.0023.

Gentry, G. , and D.Alderman . 2015. ““‘A City Built upon Its Dead”: The Intersection of Past and Present through Ghost Walk Tourism in Savannah, Geogia.” South Carolina Review 47 (2): 49-64.

Goldstein, D. , S.Grider, and J.Thomas . 2007. Haunting Experiences: Ghosts in Contemporary Folklore . Utah: Utah State University Press.

Grydehøj, A . 2010. "Uninherited Heritage: Tradition and Heritage Production in Shetland, Åland and Svalbard.” International Journal of Heritage Studies 16 (1-2), 77-89.

Hanks, M. 2011. "Re-Imagining the National Past: Negotiating the Roles of Science, Religion, and History in Contemporary British Ghost Tourism.” In Contested Cultural Heritage, edited by H.Silverman , 125-139. New York, NY: Springer.

Hanks, M . 2016. Haunted Heritage : The Cultural Politics of Ghost Tourism, Populism, and the Past. Routledge.

Harrison-Buck, E . 2012. “Architecture as Animate Landscape: Circular Shrines in the Ancient Maya Lowlands.” American Anthropologist 114(1), 6480. doi:10.1111/aman.2012.114.issue-1.

Harvey, G . 2005. Animism : Respecting the Living World. Wakefield Press. 
Hemme, D. 2005. "Landscape, Fairies and Identity: Experience on the Backstage of the Fairy Tale Route." Journal of Tourism and Cultural Change 3 (2): 71-87.

doi:10.1080/09669580508668488.

Henriques, C. , and M. J.Custódio , 2008. "Folk Dancing, Tourism and Identity. A Relationship in (De) Construction?" 16th ICOMOS General Assembly and International Symposium: 'Finding the spirit of place - between the tangible and the intangible', Quebec, Canada, September 29 - October 42008.

Hill, A. 2010. Paranormal Media: Audiences, Spirits and Magic in Popular Culture . Abingdon: Routledge.

Holloway, J. 2010. "Legend-Tripping in Spooky Spaces: Ghost Tourism and Infrastructures of Enchantment." Environment and Planning: D Society \& Space 28 (4): 618-637. doi:10.1068/d9909.

Holmes, G. , Smith, T. A. and Ward, C . 2018. Fantastic Beasts and Why to Conserve them: Animals, Magic and Biodiversity Conservation. Oryx, 52(2): 231-239. doi:10.1017/S003060531700059X.

Hopper, N. G. , A. G.Gosler, J. P.Sadler, and S. J.Reynolds . 2019. “Species’ Cultural Heritage Inspires a Conservation Ethos: The Evidence in Black and White." Conservation Letters 12 (3): e12636. doi:10.1111/conl.12636. 
Hunter, J . 2019. Greening the Paranormal : Exploring the Ecology of Extraordinary Experience. August Night Press.

Inglis, D. , and M.Holmes . 2003. "Highland and Other Haunts: Ghosts in Scottish Tourism." Annals of Tourism Research 30 (1): 50-63. doi:10.1016/S0160-7383(02)00031-2.

Ironside, R. 2018. “The Allure of Dark Tourism: Legend-Tripping and Ghost Seeking in Dark Places." In The Supernatural in Society, History and Culture, edited by D.Waskul and M.Eaton, 95-115. Pennsylvania: Temple University Press.

Kirshenblatt-Gimblett, B . 2004. "Intangible Heritage as Metacultural Production 1.” Museum international 56 (1\#2): 52-65. doi:10.1111/j.1350-0775.2004.00458.x

Kolås, Å. 2004. “Tourism and the Making of Place in Shangri-La.” Tourism Geographies 6 (3): 262-278. doi:10.1080/1461668042000249610.

Larsen, J. and J. Urry . 2011. "Gazing and Performing.” Environment and Planning D: Society and Space 29(6): 1110-1125. doi:10.1068/d21410.

Light, D. 2007. "Dracula Tourism in Romania Cultural Identity and the State." Annals of Tourism Research 34 (3): 746-765. doi:10.1016/j.annals.2007.03.004.

Malkki, L. 1995. Purity and Exile: Violence, Memory and National Cosmology among Hutu Refugees in Tanzania . Chicago: University Chicago Press. 
Mathe-Soulek, K. , G.Aguirre, and I.Dallinger . 2016. "“‘'You Look like You’ve Seen A Ghost": A Preliminary Exploration in Price and Customer Satisfaction Differences at Haunted Hotel Properties.” Journal of Tourism Insights 7 (1): 1-13. doi:10.9707/23280824.1058.

Mattar, S. G. 2012. "Yeats, Fairies, and the New Animism." New Literary History 43

(1): 137-157. doi:10.1353/nlh.2012.0006.

McCann, G. and Y. C.Hsu . 2014. "Haunted Headwaters: Ecotourism, Animism, and the Blurry Line Between Science and Spirits." In SHS Web of Conferences , Vol. 12, p. 01054. EDP Sciences.

McEwan, C . 2008. “A Very Modern Ghost: Postcolonialism and the Politics of Enchantment.” Environment and Planning D: Society and Space 26(1): 29-46. doi:10.1068/d460t.

Meehan, E. R. 2008. “Tourism, Development, and Media.” Society 45 (4): 338-341. doi:10.1007/s12115-008-9111-7.

Muir, T. 2019. "Assipattle and the Stoor Worm.” In The Anthology of Scottish Folklore , 1827. Gloucestershire: History Press.

Orkney Folklore Trail . 2019. Accessed 29 May 2020. https://www.orkneyology.com/orkney$\underline{\text { folklore-trail.html }}$ 
Orkney Storytelling

Festival. 2019. Accessed 05 April 2020. https://www.orkneystorytellingfestival.co.uk

Orkney Volume Tourism Management Survey: Report for the Orkney Islands Council and Highlands and Islands Enterprise . 2017. Accessed 20 May

2020. https://www.orkney.gov.uk/Files/Committees-and-

Agendas/Development\%20and\%20Infrastructure/DI2017/12-09-

2017/I12_App1_Volume_Tourism_Management_Study.pdf

Paphitis, T. 2013. “'Have You Come to Take the King Away?': A Survey of Archaeology and Folklore in Context." Papers from the Institute of Archaeology 23 (1).

doi:http://dx.doi.10.5334/pia.434.

Pritchard, A. and N. Morgan . 2006. "Hotel Babylon? Exploring Hotels as Liminal Sites of Transition and Transgression.” Tourism Management 27(5): 762772. doi:10.1016/j.tourman.2005.05.015.

Ross, L. 2019. "Locals rebel against stone stacks tourist trend on Skye.” Accessed 05 April 2020. https://www.thetimes.co.uk/article/locals-rebel-against$\underline{\text { stone-stacks-tourist-trend-on-skye-qj2g3fdwf }}$

Ross-shire Journal . 2020. "Loch ness monster sightings reach record level.” Accessed 05 April 2020. https://www.ross-shirejournal.co.uk/news/monster-level-of$\underline{\text { nessie-sightings-189438/ }}$ 
Sellers, I . 2010. "Bordering on the Supernatural: Merging Animism and the Frontier in Archaeology." PlatForum $11:$ 77-88.

Shaw, V. 2016. "Isle of Skye voted 'most desirable place' to live in britain.” Accessed 05 April 2020. https://www.independent.co.uk/news/uk/home-news/most$\underline{\text { desirable-place-to-live-britain-isle-of-skye-devon-a7422051.html }}$

Sheller, M. , and J. Urry . 2004. Tourism Mobilities: Places to Play, Places in Play. Routledge.

Smith, D. 2019. "Foreword." In The Anthology of Scottish Folklore . Gloucestershire: History Press.

Stenner, P. 2018. Liminality and Experience: A Transdisciplinary Approach to the Psychosocial . Palgrave Macmillan: London.

Storey, J. 2009. Inventing Popular Culture: From Folklore to Globalization . Blackwell Publishing: London.

The Herald . 2017. "Orkney under threat from cruise ship ‘invaders'.” Accessed 05 April 2020. https://www.heraldscotland.com/news/15526001.orkne y-under-threat-from-cruise-ship-invaders/ 
The Press and Journal . 2018. "Loch ness monster worth nearly $£ 41 \mathrm{~m}$ a year to scottish economy." Accessed 05 April 2020. https://www.pressandjournal.co.uk/fp/news/highlands/1 562103/loch-ness-monster-worth-nearly-41m-a-year-to-scottish-economy/

The Scotsman . 2019. "Anger as tourists of Skye "making stone circles to impress instagram followers." Accessed 29 May 2020. https://www.scotsman.com/heritage-andretro/heritage/anger-tourists-skye-making-stone-circles-impress-instagram-followers$\underline{1403365}$

The Times . 2019. “Oldest tree threatened by tourists seeking souvenirs.” Accessed 20 May 2020. https://www.thetimes.co.uk/article/oldest-tree-threatened-by-tourists-seeking$\underline{\text { souvenirs- } 7708059 \mathrm{wl}}$

Thompson, R. 2010. ““Am I Going to See a Ghost Tonight?’: Gettysburg Ghost Tours and the Performance of Belief." The Journal of American Culture 33 (2): 79-91. doi:10.1111/j.1542-734X.2010.00735.x.

Tunbridge, J. 1994. “Whose Heritage? Global Problem, European Nightmare.” In Building a New Heritage: Tourism, Culture and Identity in the New Europe, edited by G.Ashworth and P.Larkham , 123-134. London: Routledge.

Turner, V . 1982. From rRtual to Theatre. The Human Seriousness of Play. New York: PAJ Publications. 
Waskul, D. , and M.Waskul . 2016. Ghostly Encounters: The Hauntings of Everyday Life . Philadelphia: Temple University Press.

Waterton, E. , and L.Smith . 2010. "The Recognition and Misrecognition of Community Heritage.” International Journal of Heritage Studies 16 (1-2): 4-15. doi:10.1080/13527250903441671. 